\title{
Sequential Delivery of Growth Factors from Hydrolytically Degradable Silica-Based Nanoparticles for Cartilage Tissue Engineering
}

\author{
Danial Barati* \\ Department of Orthopaedic Surgery, Stanford University School of Medicine, California
}

Submission: January 25, 2018; Published: February 06, 2018

*Corresponding author: Danial Barati, Postdoctoral Researcher, Department of Orthopaedic Surgery, Stanford University School of Medicine, 300 Pasteur Dr, Edward Building Room 114,Stanford, California 94305, Tel: 8434247446; Email: dlbarati@stanford.edu

\begin{abstract}
Articular cartilage shows a very limited self-healing capability due to it's a vascular structure. It has been reported that sequential supplementation of various growth factors such as bone morphogenic protein 7 (BMP-7), transforming growth factor-beta 1 (TGF- $\beta 1$ ) and insulin-like growth factor-I (IGF-I) play critical roles in reconstruction of articular cartilage tissue. The objective of this work is to design a drug delivery system which facilitates the controlled sequential delivery growth factors to maximize the extent of chondrogenic differentiation of mesenchymal stem cells and consequently reconstruction of damaged cartilage tissue. Surface-modified silica nanoaprticles (SNs) with short segments of lactide (L) and glycolide (G) units were used for grafting and timed-release of growth factors. It was shown that by changing the length of L and G units, the release rate of grafted bovine serum albumin (BSA) on the surface of SNs can be controlled. Nanoparticles with bigger $\mathrm{G}$ units showed faster release rate of BSA compared with shorter G units. Additionally, the presence of short LG segments did not significantly change the size distribution of SNs.
\end{abstract}

\section{Introduction}

Articular cartilage can resist a significant amount of mechanical stress and provide a lubricating surface for the gliding joints and a load-bearing matrix attached to the underlying bone [1]. However, due to its avascular nature and low metabolism, it has a very limited self-repair capability upon suffering a trauma [2]. The disease control and prevention center reported that nearly 27 million Americans suffer from joint pain and stiffness, loss of function and disability [3]. While various strategies such as transplantation of autogenous or allogenous chondrocytes, or the use of mesenchymal stem cells (MSCs) are currently used for cartilage treatment, these strategies always suffer from inherent risks of an immune reaction, lack of suitable donor site, and more importantly they rarely restore the full function to the joint $[4,5]$

It has been demonstrated that different types of growth factors such as bone morphogenic protein 7 (BMP-7), transforming growth factor-beta 1 (TGF- $\beta 1$ ) and insulin-like growth factor-I (IGF-I) play critical roles in tissue engineering of articular cartilage to induce chondrogenic differentiation of Mesenchymal Stem Cells (MSCs) [6-8]. However, the bioavailability and bioactivity of these growth factors are both time and concentration dependent $[4,9,10]$. Several studies have shown that the sequential supplementation of growth these factors is critical to prevent dedifferentiation of cells by first promoting proliferation with one specific growth factor, and then differentiation and expression of a desired phenotype with another $[9,10]$. A critical barrier to progress in this way is the lack of suitable delivery systems which work for precise controlled and orchestrated time-dependent delivery of multiple growth factors, although many studies have been conducted to control the delivery of growth factors for different tissue engineering applications. Accordingly, the main challenge of this work is to engineer a programmable delivery system to control the release rate of BMP-7, TGF- $\beta 1$ and IGF-I growth factors and consequently maximize the chondrogenic differentiation of MSCs.

To address this challenge, the idea is to engineer a silica based nanoparticle system containing short segments of biodegradable polymers such as polylactic acid and polyglycolic acid to control the release rate of grated proteins (Figure 1). We have chosen MSNs given their demonstrated biocompatibility, osteogenic potential [11], and efficacy as drug delivery vehicles for sustained release of antibiotics [12] and anti-cancer drugs [13]. We envision that due to the hydrophilic nature of silica nanoparticles, bioactivity of the grafted proteins will be significantly enhanced over solid hydrophobic micro/nanoparticles such as poly lactic-coglycolic acid (PLGA) which are currently used for drug delivery 
applications. Accordingly, we assume that the protein release rate can be tuned by type or length of the degradable segments. The novelty of this project is to design a low-cost hydrolytically degradable nanocarrier system which facilitates a programmable sequential delivery of multiple growth factors with a controlled timed-release to enhance chondrogenic differentiation of MSCs for cartilage tissue engineering applications.

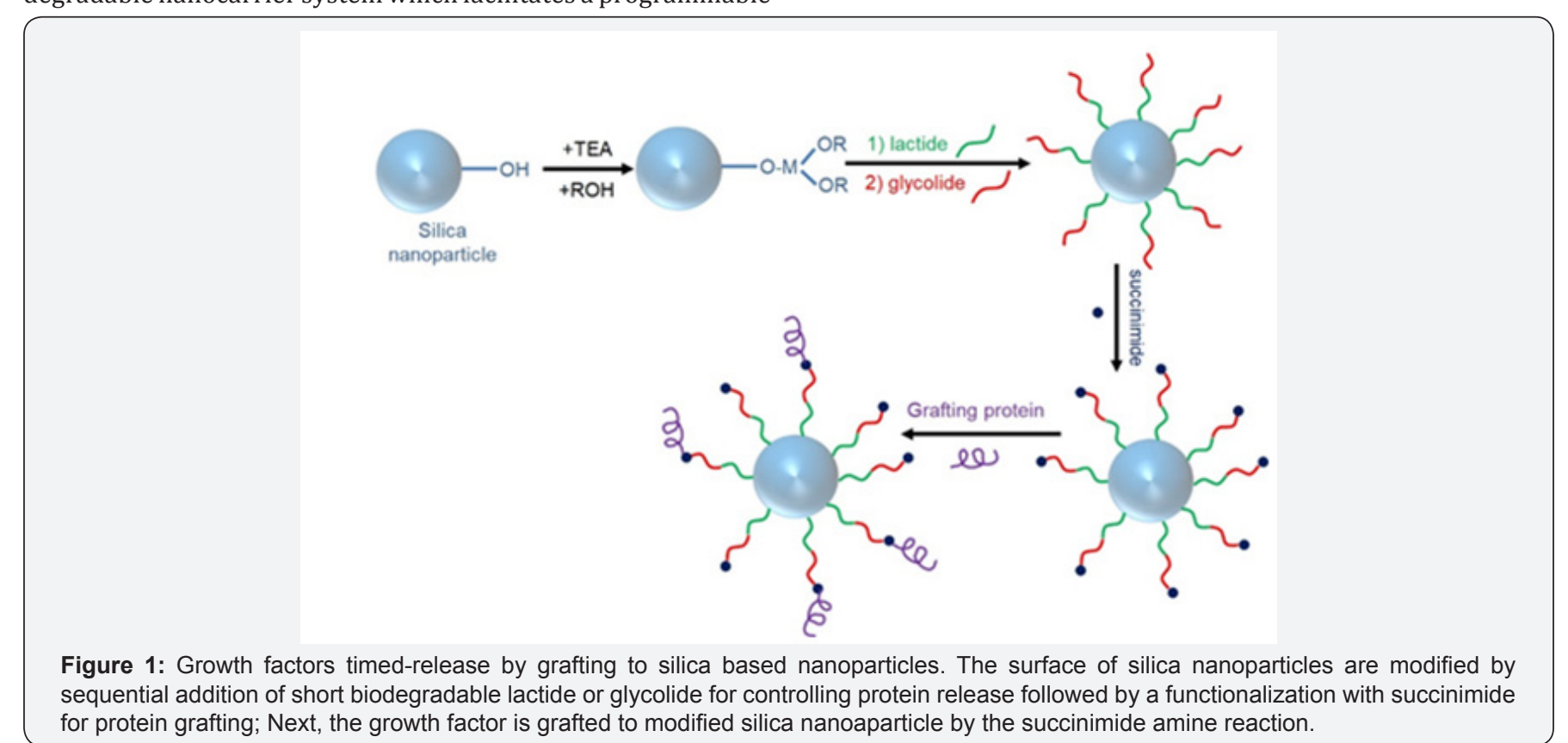

\section{Materials and Methods}

Materials: Lactide (L) and glycolide (G) monomers with $>99.5 \%$ purity (Ortec, Easley, SC) were dried under vacuum at $40^{\circ} \mathrm{C}$ for at least $12 \mathrm{~h}$ before use. N, N/-disuccinimidyl carbonate (DSC) and bovine serum albumin (BSA) were received from Novabiochem (EMD Biosciences, San Diego, CA) and Jackson Immuno Research (West Grove, PA), respectively. Hydrophilic silica nanoparticles (SN) was kindly donated by Evonik Corporation (New Jersy). All other reagents were purchased from Sigma Aldrich (St. Louis, MO).

Methods: To activate the silanol groups of SNs were activated by adding $1.5 \times 10-4 \mathrm{~mol}$ triethyl amine (TEA) to $250 \mathrm{mg}$ of SN containing $3 \times 10-4 \mathrm{~mol} \mathrm{SiOH}$ groups in $70 \mathrm{ml}$ toluene as the solvent. In the next step, $6 \times 10-4 \mathrm{~mol}$ of isopropyl alcohol was added to the mixture to continue the reaction for $2 \mathrm{~h}$ at $50 \stackrel{\circ}{\circ}$. Then, the desired amount of $\mathrm{L}$ was added to the mixture along with $1 \mathrm{ml}$ tin (II) 2-ethylhexanoate as the reaction catalyst and the reaction was run for $6 \mathrm{~h}$. The lactide chain-extended silica was used as an initiator for chain extension with $\mathrm{G}$ monomer with a predetermined $\mathrm{L}$ to $\mathrm{G}$ ratio. The reaction was allowed to proceed for $6 \mathrm{~h}$ at $50^{\circ} \mathrm{C}$ and the product was precipitated in ice-cold hexane to remove the unreacted monomers. In separate reactions, the mole ratio of $\mathrm{L}$ and $\mathrm{G}$ was changed from $100 \%$ (L100) to $75 \%$ (L75/G25) and 50\% (L50/G50) while the total amount of $L$ and $G$ was kept fixed at $3 \times 10-3$ mol. The synthesized copolymer on SNs surface was functionalized with succinimide groups by reacting hydroxyl end-groups of the copolymer with DSC as we described previously [14]. The product was purified by dialysis against DI water and lyophilized.
To attach BSA on the surface of modified SNs, $10 \mathrm{mg}$ SNs was suspended in $0.5 \mathrm{~mL}$ PBS by sonication for $1 \mathrm{~min}$. Next, $0.5 \mathrm{~mL}$ of the protein in PBS $(20 \mathrm{mg} / \mathrm{mL}$ for BSA) was added to the SNs suspension. The amine group of the protein was allowed to react with succinimide end-groups of LG in the surface of SNs under ambient conditions for $12 \mathrm{~h}$ as we previously described (Figure 1) [15]. The protein grafted SNs were freeze-dried to obtain a free-flowing powder. To determine grafting efficiency, the protein grafted SNs were resuspended in PBS and centrifuged at $18,000 \mathrm{rcf}$ for $10 \mathrm{~min}$ and the supernatant was analyzed for total protein content with the ninhydrin reagent as we described previously [16]. Grafting efficiency was determined by dividing the amount of attached protein (total - free protein) by the initial amount in the grafting reaction.

Size distribution of the SNs was measured by dynamic light scattering with a Submicron Particle Sizer (Model 370, NICOMP, Santa Barbara, CA) as described previously [16,17]. For measurement of release kinetic, $1 \mathrm{mg}$ protein grafted SNs were incubated in $1 \mathrm{~mL} \mathrm{PBS}$ at $37^{\circ} \mathrm{C}$ as we previously described [15]. At each time point, the suspension was centrifuged at $18350 \mathrm{rcf}$ for $10 \mathrm{~min}$, the supernatant was removed, the SNs were resuspended in $1 \mathrm{~mL}$ fresh PBS and incubated until the next time point. The amount of BSA in the supernatant was measured with the ninhydrin reagent as described $[16,18]$.

\section{Results and Discussion}

The calculated grafting efficiency of BSA to SNs based on the procedure explained in the method section was $52 \pm 9 \%$. The effect of $\mathrm{L}$ and $\mathrm{G}$ segments on average diameter and size distribution of nanoparticles are shown in (Figure 2a). It can 
be observed the addition of short L and G parts in SNs does not significantly change the average diameter of particles. The particle sizes are between $120 \pm 12$ and $165 \pm 15$ for SN and SNL100, respectively. Figure $2 b$ reveals the effect of the length of $L$ and $\mathrm{G}$ segments on release rate of BSA from nanoparticles. The results demonstrated that by increasing the length of lactide the release rate of BSA will decrease significantly. The cumulative release percentage of BSA is $51 \pm 5,65 \pm 8$ and $91 \pm 4$ for L50/ G50, L75/G25 and L100, respectively, after 24 days. The average release rate of BSA from L50/G50, L75/G25 and L100 is 3.2, 2.4 and $2.1 \mathrm{wt} \%$, respectively, during the first 24 days.
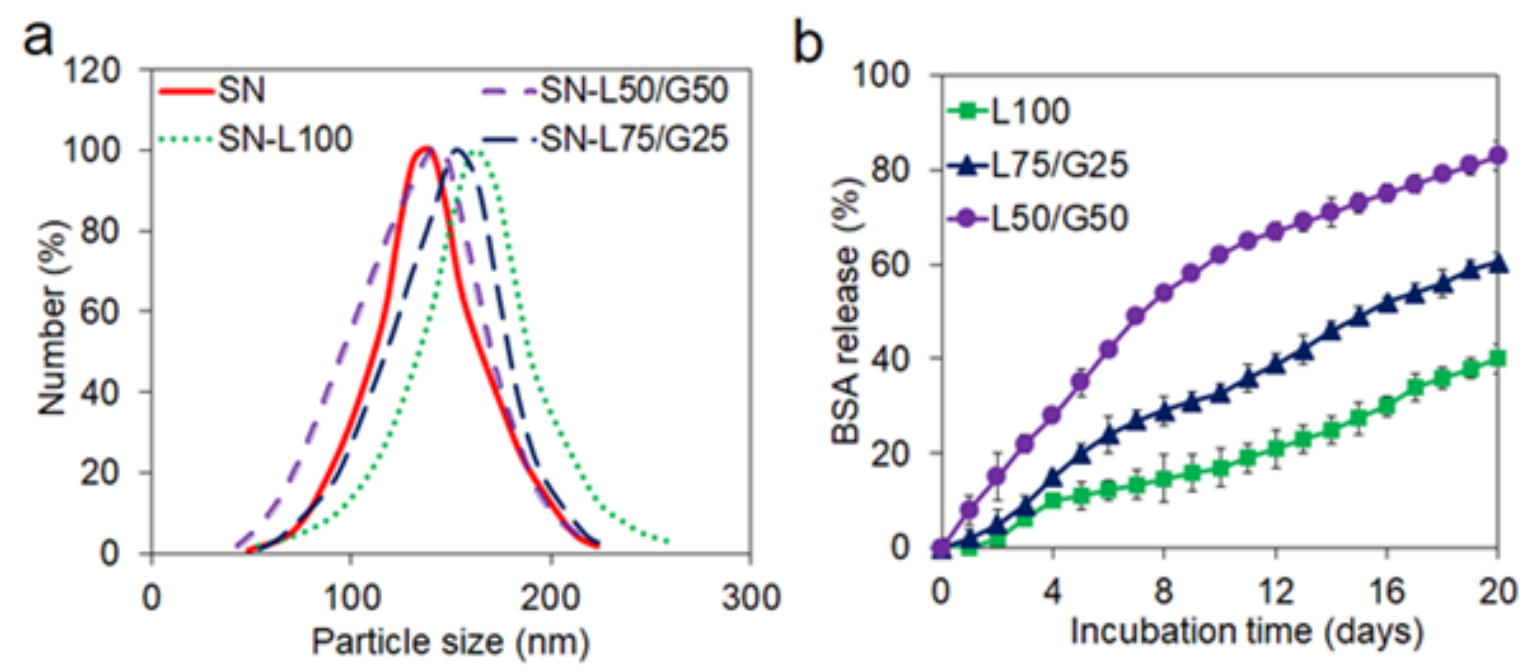

Figure 2: Effect of L/G ratio on SNs size distribution (a) and cumulative BSA release in PBS with incubation time (b). The abbreviations SN, L and G represent silica nanoparticles, lactide and glycolide, respectively. The abbreviations L100, L75/G25 and L50/G50 represent the ratio of $L$ to $G$ with $100 \%, 75 \%$, and $50 \%$ lactide, respectively, in a constant length of $L G$ segments. Error bars correspond to means \pm 1 SD for $n=3$.

It has been reported that the release kinetic of BSA grafted to the PLG copolymer follows the degradation rate of the copolymer [19]. Additionally, it has been previously shown that the degradation kinetic of LG based micelles depends on the proximity of water molecules to L and G ester groups [20,21], which is dependent on hydrophobicity of the degradable units [19]. Therefore, the fraction of less hydrophobic G in LG segments has a profound effect on LG unit degradation and consequently the release rate of protein. As a result, by increasing the fraction of $\mathrm{G}$, which is less hydrophobic than $\mathrm{L}$, from 0 to $50 \%$, the the average release rate of BSA increased from $2.1 \mathrm{wt} \%$ to $3.2 \mathrm{wt} \%$.

\section{Conclusion}

It was shown that by surface modification of silica nanoparticles with short segments of lactide and glylcolide, the controlled release of growth factors can be achieved. Based on the release profile of BSA from surface modified silica nanopartilces, by increasing the ratio of glycolide segment from $0 \%$ to $50 \%$ with respect to lactide segment, the average release rate of BSA will increase from $2.1 \mathrm{wt} \%$ to $3.2 \mathrm{wt} \%$ per day. Some of the potential challenges of using nanoparticulate systems for drug delivery applications are the stability of the nanoparticles in aqueous environment, bioactivity of growth factors and controlling release mechanism of growth factors from nanoparticles. Therefore, further studies need to be done on the properties of surface modified nanoparticles as well as controlled release of target growth factors like of BMP-7, TGF- $\beta 1$ and IGF-Iand their effect on chondrogenic differentiation of MSCs.

\section{References}

1. Karimi T, Barati D, Karaman O, Moeinzadeh S, Jabbari E (2015) A developmentally inspired combined mechanical and biochemical signaling approach on zonal lineage commitment of mesenchymal stem cells in articular cartilage regeneration. Integr Biol (Camb) 7(1): 112-127.

2. Hunziker EB (1999) Biologic repair of articular cartilage: Defect models in experimental animals and matrix requirements. Clin Orthop Relat Res (367 Suppl): S135-S146.

3. Yang, PJ, Temenoff JS (2009) Engineering orthopedic tissue interfaces. Tissue Eng Part B Rev 15(2): 127-141.

4. Worster AA, Toland BDB, Fortier LA, Bent SJ, Williams J, et al. (2001) Chondrocytic differentiation of mesenchymal stem cells sequentially exposed to transforming growth factor-beta 1 in monolayer and insulin-like growth factor-I in a three-dimensional matrix. J Orthop Res 19(4): 738-749.

5. Klein TJ, Malda J, Sah RL, Hutmacher DW (2009) Tissue engineering of articular cartilage with biomimetic zones. Tissue Eng Part B Rev 15(2): 143-157.

6. Takahashi T, Ogasawara T, Kishimoto J, Liu G, Asato H, et al. (2005) Synergistic effects of FGF-2 with insulin or IGF-I on the proliferation of human auricular chondrocytes. Cell Transplant 14(9): 683-693.

7. van der Kraan PM, Buma P, van Kuppevelt T, van den Berg WB (2002) Interaction of chondrocytes, extracellular matrix and growth factors: relevance for articular cartilage tissue engineering. Osteoarthritis and Cartilage 10(8): 631-637.

8. Kolf CM, Cho E, Tuan RS (2007) Mesenchymal stromal cells: biology of adult mesenchymal stem cells: regulation of niche, self-renewal and differentiation. Arthritis research \& therapy 9(1): 204. 
9. Pei M, Seidel J, Novakovic GV, Freed LE (2002) Growth factors for sequential cellular de-and re-differentiation in tissue engineering. Biochem Biophys Res Commun 294(1): 149-154.

10. Martin I, Suetterlin R, Baschong W, Heberer M, Novakovic GV, et al. (2001) Enhanced cartilage tissue engineering by sequential exposure of chondrocytes to FGFâ€2 during 2D expansion and BMPâ€2 during 3D cultivation. Journal of cellular biochemistry 83(1): 121-128.

11. Areva S, Ääritalo V, Tuusa S, Jokinen M, Lindén M, et al. (2007) Sol-Gelderived TiO2-SiO2 implant coatings for direct tissue attachment. Part II: Evaluation of cell response. Journal of Materials Science: Materials in Medicine 18 (8): 1633-1642.

12. Olmo LM, Nicolás MR, Ortega VV, Baños MA, Sainz MC, et al. (2006) A bioactive sol-gel glass implant for in vivo gentamicin release. Experimental model in Rabbit. J Orthop Res 24(3): 454-460.

13. Kortesuo P, Ahola M, Karlsson S, Kangasniemi I, Yli-Urpo A, et al. (2000) Silica xerogel as an implantable carrier for controlled drug deliveryevaluation of drug distribution and tissue effects after implantation. Biomaterials 21(2): 193-198.

14. Huang CH, Wang FC, Ko BT, Yu TL, Lin CC (2001) Ring-opening polymerization of $\varepsilon$-caprolactone and L-lactide using aluminum thiolates as initiator. Macromolecules 34(3): 356-361.

15. Barati D, Shariati SRP, Moeinzadeh S, Martin JMM, Khademhosseini A, et al. (2016) Spatiotemporal release of BMP-2 and VEGF enhances osteogenic and vasculogenic differentiation of human mesenchymal

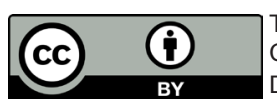

This work is licensed under Creative Commons Attribution 4.0 Licens DOI: 10.19080/JHNSS.2018.02.555583 stem cells and endothelial colony-forming cells co-encapsulated in a patterned hydrogel. J Control Release 223: 126-136.

16. Mercado AE, He X, Xu W, Jabbari E (2008) The release characteristics of a model protein from self-assembled succinimide-terminated poly (lactide-co-glycolide ethylene oxide fumarate) nanoparticles. Nanotechnology 19(32): 325609.

17. Eskandari S (2006) Optimization of Emulsan Production by A calcoaceticus RAG-1. Amirkabir University of Technology.

18. Eskandari S, Rashedi H, Shirkolaee YZ, Assadi MM, Jamshidi E, et al. (2009) Evaluation of oil recovery by rhamnolipid produced with isolated strain from Iranian oil wells. Annals of microbiology 59(3): 573-577.

19. Barati D, Moeinzadeh S, Karaman O, Jabbari E (2014) Time dependence of material properties of polyethylene glycol hydrogels chain extended with short hydroxy acid segments. Polymer (Guildf) 55(16): 3894 3904.

20. Moeinzadeh S, Barati D, Sarvestani SK, Karaman O, Jabbari E (2013) Nanostructure formation and transition from surface to bulk degradation in polyethylene glycol gels chain-extended with short hydroxy acid segments. Biomacromolecules 14(8): 2917-2928.

21. Barati D, Walters JD, Shariati SR, Moeinzadeh S, Jabbari E (2015) Effect of organic acids on calcium phosphate nucleation and osteogenic differentiation of human mesenchymal stem cells on peptide functionalized nanofibers. Langmuir 31(18): 5130-5140.

\section{Your next submission with Juniper Publishers will reach you the below assets}

- Quality Editorial service

- Swift Peer Review

- Reprints availability

- E-prints Service

- Manuscript Podcast for convenient understanding

- Global attainment for your research

- Manuscript accessibility in different formats

( Pdf, E-pub, Full Text, Audio)

- Unceasing customer service

Track the below URL for one-step submission https://juniperpublishers.com/online-submission.php 